\title{
芯鉄骨合成柱の耐震性能に関する実験的研究 \\ EXPERIMENTAL STUDY OF EARTHQUAKE RESISTANT PROPERTIES OF COMPOSITE COLUMNS USING CORE STEEL
}

\author{
堺 純一*, 松井千秋**, 南宏一***, 平川葉子**** \\ Junichi SAKAI, Chiaki MATSUI, Koichi MINAMI \\ and Yoko HIRAKAWA
}

\begin{abstract}
This paper present the results of an experimental work carried out to study the elastic-plastic behavior of composite columns using core steel under constant vertical and varying horizontal loads. Area and shape of cross section of core steel and axial load ratios were selected as test parameters. Composite columns using core steel were able to hold large axial load up to rotation angle equals $5 / 100 \mathrm{rad}$. On the other hand reinforced concrete columns were not able to hold axial load at last. From the test results it can be thought the composite columns using core steel can prevent structural buildings under large horizontal and vertical accelerations from story failure.
\end{abstract}

Keywords: flexural strength, deformation capacity, collapse, aria of core steel, shape of core steel, axial load ratio 曲げ耐力, 変形能力, 崩壊, 芯鉄骨量, 芯鉄骨形状, 軸力比

\section{1. 序}

兵庫県南部地震では，鉄筋コンクリート（以下， RC と略記）建 物において，柱が曲げ降伏したのちにせん断破壊を起こし，鉛直荷 重を支えきれず，層崩壊を起こした建物が少なくなかった。特に変 動軸力を受け高軸力下におかれた隅柱の破壊が層崩壊につながった ものと考えられる。

このような層崩壊につながる柱の崩壊を防ぐRC柱の補強方法と して，帯筋を密に巻く方法あるいはRC断面を鋼管で覆う方法など があるが、これらは鉄筋あるいは鋼管によるコンクリートを拘束す る働きに期待するものであり，有効な補強方法と考えられる ${ }^{1}$ 。こ れと翼なる考え方から， RC 断面の芯に鉄骨を挿入し，コンクリー 卜断面の中心軸の圧縮ひずみの進展を抑制させる方法もあると考え られる，RC柱では主筋の座屈が軸力保持不能の崩壊形に直接つな がるため, 芯鉄骨を挿入することにより主筋のひずみの進行を抑制 できること，さらに主筋が座屈しコンクリートが圧壊した後も内蔵 鉄骨が軸力を保持できる程度に挿入されていれば, 軸力を支持でき ることが期待でき，層崩壊を免れるものと考えられる．

小鉄骨を挿入したSRC 柱に関する研究は以前にも報告されてお り, 特に高強度帯筋を用いた場合の性状が調べられ, 中心㢶実験 により, 高強度せん断補強筋を用いた場合, 最大耐力を発揮した後,
耐力低下の少ない性状を示すこと,さらに，曲げせん断実験により， せん断および曲げで耐力が決まる柱の挙動が調べられており，それ ぞれの耐力評価法が示されている21,31. しかしながら芯鉄骨合成柱 として有効に働く鉄骨の量についての検討はあまりなされていない. このような芯鉄骨合成柱では柱の弾塑性性状および崩壊性状に及ほ 寸柱の作用軸力と内蔵鉄骨量は重要なパラメー夕の一つと考えられ る.

著者らは芯鉄骨合成柱を $\mathrm{RC}$ 柱の耐震補強の一つと考え，施工の 簡便さおよび酎震性能向上の観点より，密にせん断補強笳を巻かな くとも RC柱の中心に軸力に抵抗する芯鉄骨を挿入することにより， 高軸力下においてコンクリートおよび主筋のひずみの准行の抑制効 果が得られるものと考え，通常 RC 柱に用いられるものと考之られ るせん断補強筋量を配し載荷実験を行った。

本論文では，地震時荷重を受ける柱部材を想定した載荷実験を行 い,柱の断面圧縮耐力に対する作用軸力の比と芯鉄骨の量および芯 鉄骨の形状が柱の挙動に及ほす影響を調べ，RC柱に対する耐霞補 強効果を検討することを主目的とした。さらに，比較実験のために 鉄骨鉄筋コンクリート（以下，SRCと略記）柱の載荷実験を行い, 鉄骨鉄筋コンクリート構造設計規準 ${ }^{4}$ に定義してある制限軸力のも とでの通常 SRC 柱と芯鉄骨合成柱の挙動の比較検討を行った。

\footnotetext{
* 九州大学大学院人間環境学研究科 助手.工修

** 九州大学大学院人間環境学研究科 教授・工博

*** 福山大学工学部建築学科 教授. 工博

**** 構造計画研究所構造設計部工修
}

Research Assistant, Division of Architecture, Graduate School of Human Environment Studies, Kyushu University, M. Eng.

Prof., Division of Architecture, Graduate School of Human.Environment Studies, Kyushu University, Dr. Eng.

Prof., Dept. of Architecture, Faculty of Engineering, Fukuyama University, Dr. Eng. Kozo Keikaku Engineering, I.N.C., M. Eng. 


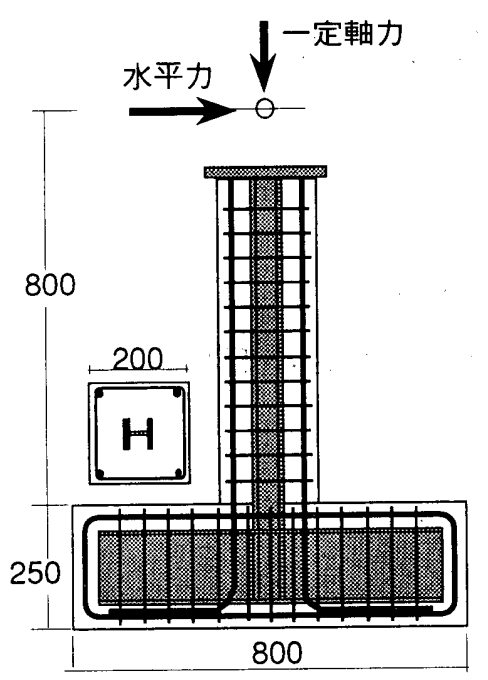

\section{2. 実験概要}

地震時における芯鉄骨合成柱の弾塑性挙動を調べるために，柱頭 に一定圧縮軸力と繰返し水平力を載荷する柱部材の実験を行った。

芯鉄骨に曲げを期待せず，軸力に抵抗させることを意図して，断 面の抵抗モーメントに㧍ける鉄骨の負担の割合が少なくなるよう， せいの小さな内蔵鉄骨を断面の中心に配置することを考え, 鉄骨せ いが柱断面せいの $1 / 3$ 以下となる断面をこここでは芯鉄骨合成柱と 定義する。

\section{1 試験体}

試験体は図1に示すような片持柱であり，断面は $200 \mathrm{~mm}$ x $200 \mathrm{~mm}$ である. 固定端から水平力加力点までの試験体材長を $800 \mathrm{~mm}$ とし， せん断スパン比を4とした。主筋はRCおよび芯鉄骨合成柱ではD16 を，SRC 断面ではD13を用いた。せん断補強笳は全試験体にD6を $50 \mathrm{~mm}$ 間隔で配し(せん断補強筋比 $\left.\mathrm{p}_{\mathrm{w}}=0.64 \%\right), 135$ 度フックを設け 主筋に緊結した。

\section{2 実験変数}

表 1 に実験条件を示す．実験変数には，1）芯鉄骨の量，2）芯鉄 骨の形状掞よび3）軸力比を選んだ。試験体は全部で 12 体である.

1）の鉄骨量として，鉄骨比（柱断面積に対する芯鉄骨断面積の

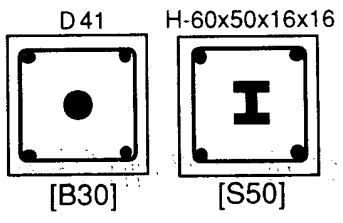

柱断面：200×200mm

主筋：D1.6（L30のみD13）

主筋間距離：140mm

帯筋：D6 (@50mm)

(全て強軸曲げとなるように鉄骨を配置)

(断面)
試験体名

S 30 - A 6

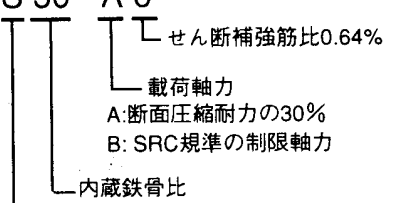

$15: 1.5 \%, 30: 3 \%, 50: 5 \%$

内蔵鉄骨形状

$S:$ 芯鉄骨 (H形鋼)

B：芯鉄骨（異形鉄筋）

$L:$ 通常SRC用H形龬

図 1 試験体

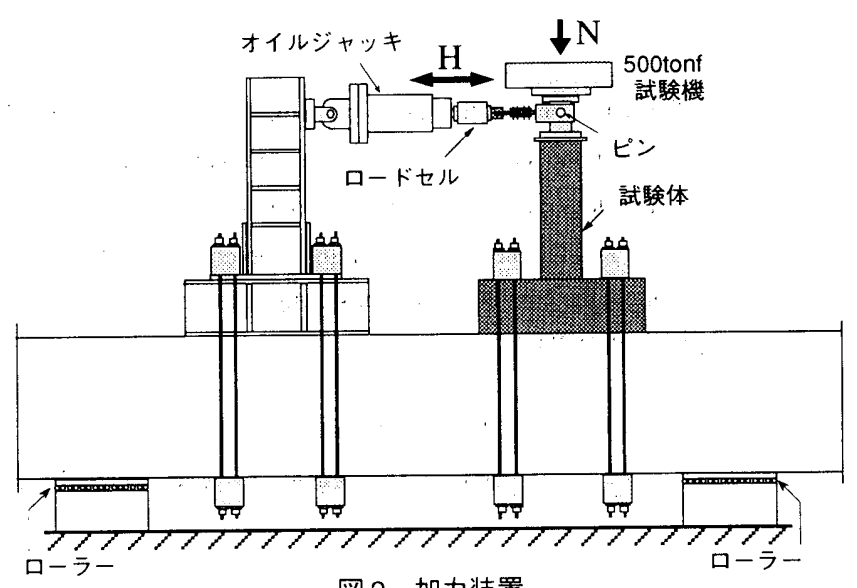

図2 加力装置

比）をパラメータにとり，3\%を標準とし，その他に $1.5 \%$ および 5 \%となるように選んだ(芯鉄骨が $\mathrm{H}$ 形鋼のみ).

2）の芯鉄骨の形状は，芯鉄骨の断面形状が柱の挙動に及ほす影 響を調べるため， H 形鋼と，曲げ抵抗がほとんど無いコンパクトな 断面である異形鉄筋（D41）の2種類を選んだ。さらに比較実験の ためにRC柱および通常 SRC柱を選んだ。主に軸力に抵抗させる鉄 骨と,曲げモーメントに抵抗させる鉄骨を用いた場合の合成断面の

表 1 実験条件

\begin{tabular}{|c|c|c|c|c|c|c|c|c|c|c|c|}
\hline \multirow[t]{2}{*}{ 試験体名 } & \multirow[t]{2}{*}{ 柱構造種別 } & \multirow[t]{2}{*}{ 内蔵鉄骨 } & \multirow[t]{2}{*}{ 鉄骨比 } & \multirow{2}{*}{$\begin{array}{c}\text { 載荷軸力 } \\
\text { 計画 }\end{array}$} & \multirow{2}{*}{$\begin{array}{c}\text { 載荷軸力 } \\
\mathrm{N}(\mathrm{kN})\end{array}$} & \multicolumn{3}{|c|}{ 断面圧縮耐力 (kN) } & \multicolumn{3}{|c|}{ 軸力比 } \\
\hline & & & & & & $\mathrm{Nu}$ & $\mathrm{sNu}$ & $\mathrm{cNu}$ & $\mathrm{n}$ & $\mathrm{ns}$ & $\mathrm{nc}$ \\
\hline S15-A6 & \multirow{8}{*}{$\begin{array}{l}\text { 芯鉄骨 } \\
\text { 合成柱 }\end{array}$} & $\mathrm{H}-60 \times 30 \times 6 \times 6$ & $1.62 \%$ & \multirow{4}{*}{$\mathrm{n}=0.3$} & 418 & 1,732 & 235 & 1,252 & 0.24 & 1.78 & 0.33 \\
\hline S30-A6 & & $\mathrm{H}-60 \times 50 \times 9 \times 9$ & $3.20 \%$ & & 616 & 2,053 & 505 & 1,324 & 0.30 & 1.22 & 0.47 \\
\hline B30-A6 & & 異形鉄筋 D41 & $3.35 \%$ & & 601 & 2,003 & 489 & 1,560 & 0.30 & 1.23 & 0.39 \\
\hline S50-A6 & & $\mathrm{H}-60 \times 50 \times 16 \times 16$ & $5.12 \%$ & & 664 & 2,212 & 722 & 1,296 & 0.30 & 0.92 & 0.51 \\
\hline S15-B6 & & $H-60 \times 30 \times 6 \times 6$ & $1.62 \%$ & \multirow{4}{*}{$\begin{array}{l}\mathrm{SRC} \text { 規準 } \\
\text { 制限軸力 }\end{array}$} & 574 & 1,749 & 235 & 1,268 & 0.33 & 2.44 & 0.45 \\
\hline S30-B6 & & H- $60 \times 50 \times 9 \times 9$ & $3.20 \%$ & & 750 & 2,007 & 507 & 1,276 & 0.37 & 1.48 & 0.59 \\
\hline B30-B6 & & 異形鉄筋 D41 & $3.35 \%$ & & 747 & 2,013 & 491 & 1,304 & 0.37 & 1.52 & 0.57 \\
\hline S50-B6 & & $\mathrm{H}-60 \times 50 \times 16 \times 16$ & $5.12 \%$ & & 891 & 2,220 & 719 & 1,304 & 0.40 & 1.24 & 0.68 \\
\hline RC-A6 & \multirow{2}{*}{$\mathrm{RC}$ 柱 } & \multirow{2}{*}{-} & \multirow{2}{*}{ 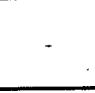 } & $\mathrm{n}=0.3$ & 467 & 1,557 & - & 1,296 & 0.30 & - & 0.36 \\
\hline RC-B6 & & & & 制限軸力 & 663 & 1,789 & - & 1,524 & 0.37 & - & 0.44 \\
\hline L30-A6 & 通常 & \multirow{2}{*}{$H-120 \times 50 \times 6 \times 6$} & \multirow{2}{*}{$3.12 \%$} & $\mathrm{n}=0.3$ & 640 & 2,133 & 471 & 1,532 & 0.30 & 1.36 & 0.42 \\
\hline L30-B6 & SRC柱 & & & 制限軸力 & 807 & 2,126 & 472 & 1,524 & 0.38 & 1.71 & 0.53 \\
\hline
\end{tabular}

1) 断面圧縮耐力： $\mathrm{Nu}$ :全断面圧縮耐力, $\mathrm{sNu}$ 鉄骨断面圧縮耐力, $\mathrm{cNu}$ :コンクリート断面圧縮耐力

2) 軸力比 : $n=N / N u, n s=N / s N u, n c=N / c N u$ 
表 2 鋼材の機械的性質

\begin{tabular}{c|c|c|c|c|c|c|l}
\hline & 規格 & 種類 & 降伏点 $\left(\mathrm{N} / \mathrm{mm}^{2}\right)$ & 引張強度 $\left(\mathrm{N} / \mathrm{mm}^{2}\right)$ & 降伏比 & 破断伸び $(\%)$ & \multicolumn{1}{|c}{ 備 考 } \\
\hline 内蔵鉄骨 & SM490 & $6 \mathrm{~mm}$ 厚鋼板 & 392 & 539 & 0.73 & 25.7 & S15試験体のフランジとウエブ \\
& SM490 & 9mm厚鋼板 & 421 & 557 & 0.76 & 22.9 & S30試験体のフランジとウエブ \\
& SM490 & $16 \mathrm{~mm}$ 厚鋼板 & 359 & 527 & 0.68 & 21.5 & S50試験体のフランジとウエブ \\
& SD295 & D41 & 366 & 554 & 0.66 & 16.5 & B30試験体の芯鉄骨 \\
\hline 主筋 & SD295 & D16 & 330 & 487 & 0.68 & 22.4 & L30試験体以外 \\
& SD295 & D13 & 343 & 510 & 0.67 & 23.0 & L30試験体 \\
\hline 带筋 & SD295 & D6 & 408 & 538 & 0.76 & 22.9 & 全試験体 \\
\hline
\end{tabular}

表 3 コンクリートの調合

\begin{tabular}{|c|c|c|c|c|c|c|c|c|c|}
\hline \multirow{2}{*}{$\begin{array}{c}\text { コンクリート } \\
\text { 種類 }\end{array}$} & \multirow{2}{*}{$\begin{array}{l}\text { 設計強度 } \\
\left(\mathrm{N} / \mathrm{mm}^{2}\right)\end{array}$} & \multirow{2}{*}{$\begin{array}{l}\begin{array}{l}\text { スランプ } \\
(\mathrm{cm})\end{array} \\
\end{array}$} & \multirow{2}{*}{$\begin{array}{c}\text { 水セメント比 } \\
(\%) \\
\end{array}$} & \multirow{2}{*}{$\begin{array}{c}\text { 細骨材比 } \\
(\%) \\
\end{array}$} & \multicolumn{5}{|c|}{ 調合 $\left(\mathrm{kg} / \mathrm{m}^{3}\right)$} \\
\hline & & & & & 水 & セメント & 細骨材 & 粗骨材 & 混和剑 \\
\hline 普通セメント & 26.5 & 18 & 49 & 44.1 & 190 & 388 & 724 & 1020 & 0.97 \\
\hline
\end{tabular}

挙動の違いを検討するためにSRC柱を実験変数に加えており，鉄骨 比 3\%の芯鉄骨合成柱（S30，B30シリーズ）の挙動と比較するため にSRC柱の鉄骨比を $3 \%$ としている。なお，全試験体とも内蔵鉄骨 は強軸曲げとなるように配している。

3）高軸力下における挙動を調べるため，断面圧縮耐力に対する 作用軸力の比（軸力比 $\mathrm{n}$ ) として 0.3 を選んだ。さらに高軸力となる, $\mathrm{SRC}$ 規準 ${ }^{4}$ に従う制限軸力（コンクリート断面の圧縮耐力の $1 / 3$ と 鋼材の圧縮耐力の $2 / 3$ の和）を実験变数に選んだ．SRC替準に従う 制限軸力を載荷した試験体の軸力比 $\mathrm{n}$ は鉄骨量により異なり，0.33 から0.40の值となっている.芯鉄骨量が柱断面の $1.5 \%$ の試験体S15B6では SRC 規準の制限軸力が断面圧縮耐力の 0.33 倍であるため, 試験体 S15-A6 は軸力比 $\mathrm{n}$ を0.3とせず，S15-B6 との違いを大きく するため, 0.24 とした。

芯鉄骨の圧縮耐力に対する作用軸力の比nsが柱の挙動に及ほす影 響が大きいと考えられるため, 鉄骨比および軸力比を変化させるこ とにより nsの值も変化させている。

表 2 に鋼材の機械的性質を示す. 表 3 にコンクリートの調合を, 表 4 に各試験体のシリンダーの圧縮強度 c $\sigma \mathrm{b}$ を示す.

\section{3 加力装置と測定方法}

加力装置は柱脚固定, 柱頭ピン支持の境界条件となるようにした (図 2 参照). 載荷は 500tonf 万能試験機で柱頭に圧縮軸力を載荷し, 一定に保持した状態で，水平力をオイルジャッキで部材角 $5 / 1000$ $\mathrm{rad}$. を単位とし各変位振幅で 1 回繰り返す漸増変位振幅で準静的に 載荷した。軸力は 500tonf 試験機の計測装置で, 水平力はオイル ジャッキ先端に取り付けたロードセルで測定した. 変位は柱頭水平 変位と軸方向変形を測定した。ただし，軸方向変形は，載荷実験中， 柱頭ピンの中心から試験体の固定端までの鉛直方向距離を測定した。

\section{4 実験結果}

\subsection{1崩壊性状}

実験は水平耐力が無くなる時点あるいは軸力を保持できない時点 で終了した. 図 3 に実験の結果得られた水平力 $\mathrm{H}$ と部材角 $\mathrm{R}$ の関倸 を示す。実験結果を表 4 に示す。

全試験体とも柱脚から断面せい上がった範囲内でのコンクリート の圧壊，剥落が激しく，この範囲内で主筋の座屈が起こった。目視 により確認した主筋の座屈発生時期を図3中に示している.かぶり コンクリートの圧壊は全ての試験体で部材角 $\mathrm{R} か ゙ 1 / 100 \sim 1.5 / 100$ rad.に生じ始め, 最大耐力を発揮した前後でかぶりコンクリートの

表 4 実験結果

\begin{tabular}{|c|c|c|c|c|c|c|c|c|c|c|c|c|c|c|c|c|}
\hline \multirow{3}{*}{$\begin{array}{c}\text { 試験体 } \\
\text { 名 }\end{array}$} & \multirow{3}{*}{$\begin{array}{c}\text { cøb } \\
\text { (Mpa) }\end{array}$} & \multirow{3}{*}{$\frac{\mathrm{N}}{\mathrm{Nu}}$} & \multirow{3}{*}{$\frac{\mathrm{N}}{\mathrm{sNu}}$} & \multirow{2}{*}{\multicolumn{2}{|c|}{$\begin{array}{l}\text { 実験曲げ耐力 } \\
\operatorname{Mmax}(k N \text { m) }\end{array}$}} & \multicolumn{4}{|c|}{ 計算曲げ耐力 } & \multirow{3}{*}{$\begin{array}{c}\text { 実験 } \\
\text { 最終状態 }\end{array}$} & \multicolumn{3}{|c|}{ 変形能力 $\mathrm{M} \geqq 0.9 \mathrm{Mmax}$} & \multicolumn{3}{|c|}{ 変形能力 $\delta \mathrm{c} \leqq 1 / 100 \mathrm{~h}$} \\
\hline & & & & & & \multirow{2}{*}{$\begin{array}{c}\mathrm{Mpcl} \\
(\mathrm{KN} \mathrm{m}) \\
\end{array}$} & \multirow{2}{*}{$\begin{array}{c}\mathrm{Mpc} 2 \\
(\mathrm{KN} \mathrm{m})\end{array}$} & \multirow{2}{*}{$\frac{\text { Mmax }}{\mathrm{Mpcl}}$} & \multirow{2}{*}{$\frac{\operatorname{Mmax}}{\overline{M p c} 2}$} & & \multirow[t]{2}{*}{ Rm90 } & \multirow{2}{*}{$\begin{array}{r}\text { Em90 } \\
(\mathrm{kN} \mathrm{m}) \\
\end{array}$} & \multirow[t]{2}{*}{$\mu \mathrm{m} 90$} & \multirow[t]{2}{*}{ Rd1 } & \multirow{2}{*}{$\begin{array}{c}\text { Edl } \\
(\mathrm{kN} \mathrm{m}) \\
\end{array}$} & \multirow[t]{2}{*}{$\mu \mathrm{d} l$} \\
\hline & & & & 正眫 & 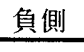 & & & & & & & & & & & \\
\hline S15-A6 & & & & & $50 ?$ & & & & 1 & & $p$ & 863 & 29.7 & $7.00 \%$ & .716 & 122.9 \\
\hline & .1 & & & & -61.4 & & & & 0.98 & & $0 \%$ & 6 & 3 & $50 \%$ & & 58.1 \\
\hline -A6 & 39.0 & 0.27 & 3 & & -61.1 & & & & 1.01 & & 10 & 4. & 0 & $6.00 \%$ & 2,8 & 91.3 \\
\hline 50-A6 & 32.4 & 0 & 92 & & 7.2 & & & & 17 & 水 & $.00 \%$ & 9 & 23.4 & $-6.00 \%$ & & 75.3 \\
\hline 5-B6 & 31.7 & & 44 & & -51.0 & & & & 1.01 & 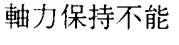 & 10 & 52 & .6 & $-4.00 \%$ & & 3 \\
\hline S30-B6 & 31.9 & 0 . & 1. & 61. & 56 & & & & 0.96 & & $0 \%$ & 490 & 4.0 & $4.50 \%$ & 1,471 & 1.1 \\
\hline $0-\mathrm{B} 6$ & 32.6 & 0.37 & 1.52 & 50.9 & -60 & & & & the & & $50 \%$ & 29 & 9.8 & $-5.00 \%$ & 1,961 & 2.3 \\
\hline 550-B6 & 32.6 & 0.40 & 24 & 617 & -60 & & & & 0.97 & 水斗 & $50 \%$ & 392 & 4 & - & & - \\
\hline RC-A6 & .4 & 0.30 & - & 51.2 & 53 & & & & 1.10 & $=7$ & $\%$ & 1 & 3.9 & $-4.00 \%$ & 1,0 & 36.8 \\
\hline RC-B6 & 38.1 & 0.37 & - & 55 & -59.2 & 50.8 & & & .02 & 軸力保持不能 & $1.50 \%$ & 10 & 3.5 & $3.00 \%$ & 549 & 15.9 \\
\hline 30-A6 & 8.3 & 30 & 36 & .1 & 8.6 & & & & & & $\%$ & $5 t$ & 11.0 & $-5.00 \%$ & 2,068 & 48.8 \\
\hline 30-B6 & 3.1 & 38 & .71 & 66.1 & -78.1 & 63.8 & 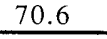 & 1010 & 1.03 & 水平力 0 & $2.00 \%$ & 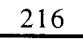 & 1.5 & $3.50 \%$ & 1,216 & 22.8 \\
\hline
\end{tabular}

1） c $\sigma \mathrm{b}$ ：コンクリートのシリンダー強度，2）計算曲げ耐力：Mpc1:鋼材の降伏応力度と $0.85 \mathrm{cob}$ を用いて計算した一般化累加強度，Mpc2 鋼材の降伏応力度と $\mathrm{c} \sigma \mathrm{b}$ を用いて計算した一般化累加強度，3) 変形能力中, Rm $90, \mathrm{Em} 90, \mu \mathrm{m} 90$ はそれぞれ, 最大曲げ耐力の $90 \%$ まで耐 力が低下した時点での部材角，その部材角までに吸収しだ累積エネルギー，図8(a)に示す塑性変形倍率。 Rd1, Ed1, $\mu$ d 1 は軸縮みが柱材長の $1 / 100$ に達した時点の部材角, 累積エネルギー, 塑性変形倍率である。 


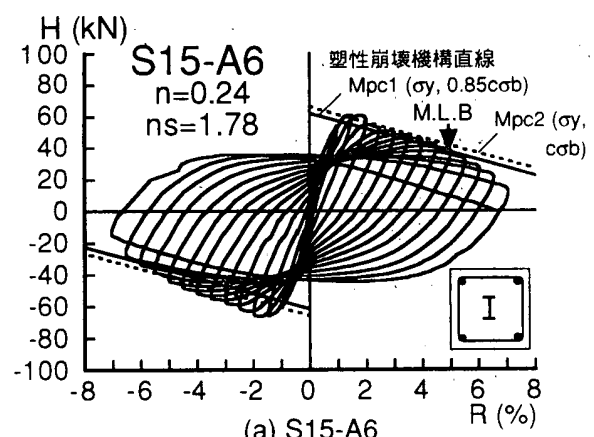

(a) S15-A6
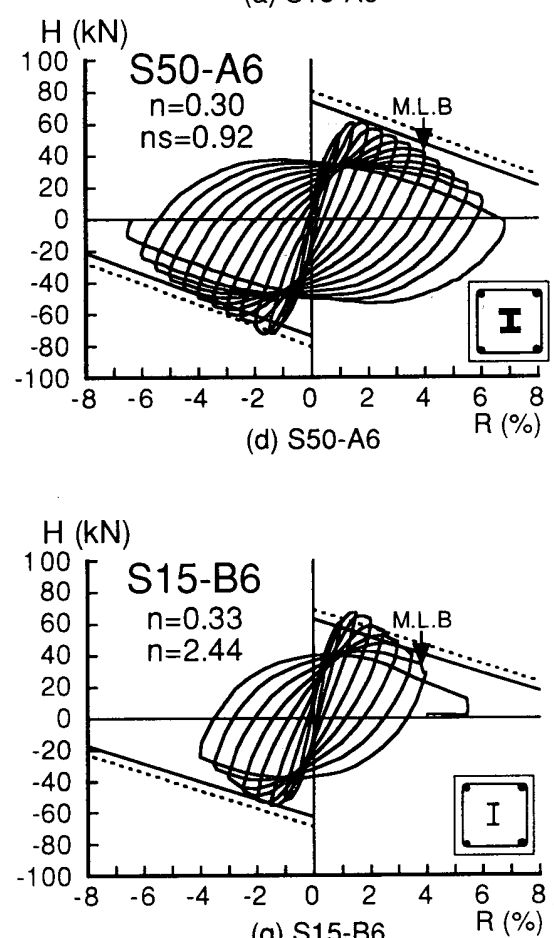

(g) S15-B6

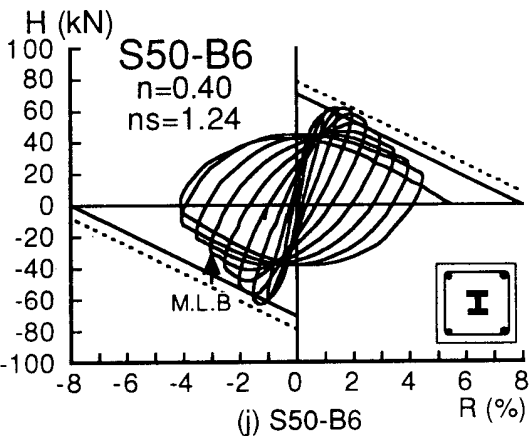

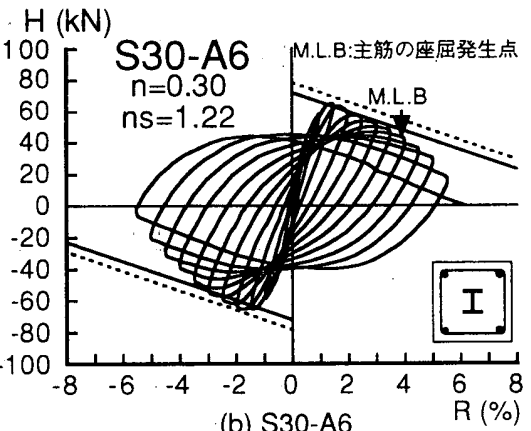

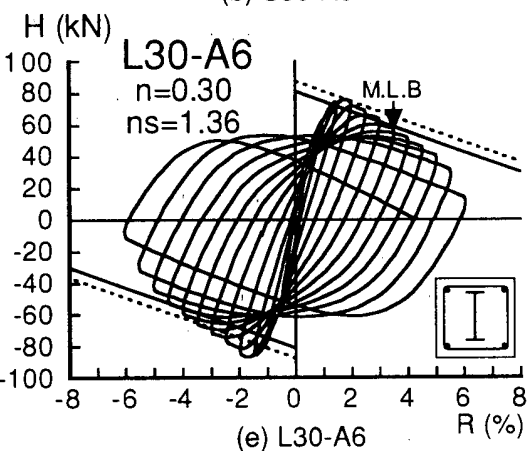

（）軸力比 $n=0.3$ の軸力載荷時
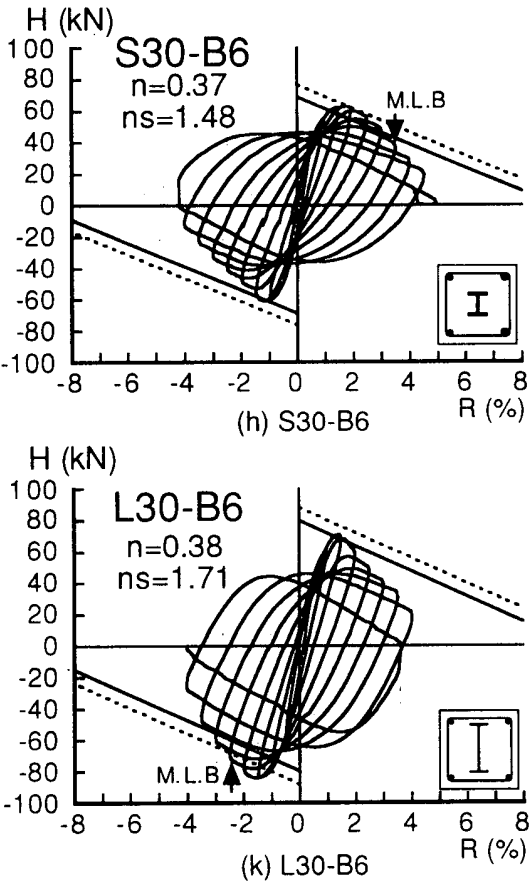

(II) SRC 規準制限軸力載荷時

図 3 水平力-部材角関係

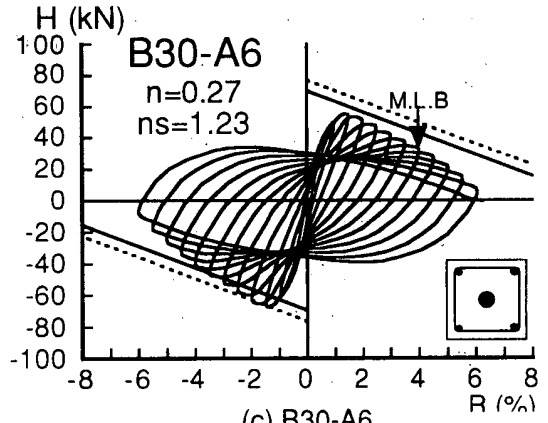

(c) B30-A6

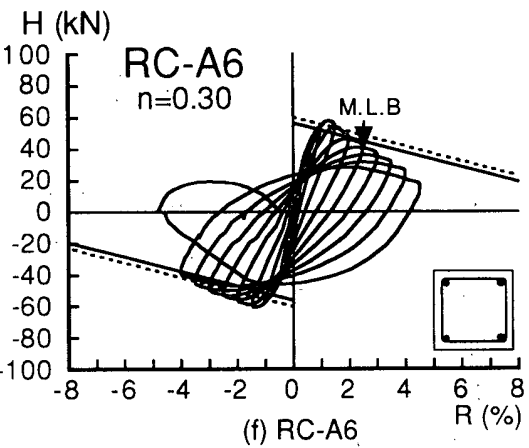

$\mathrm{H}(\mathrm{kN})$
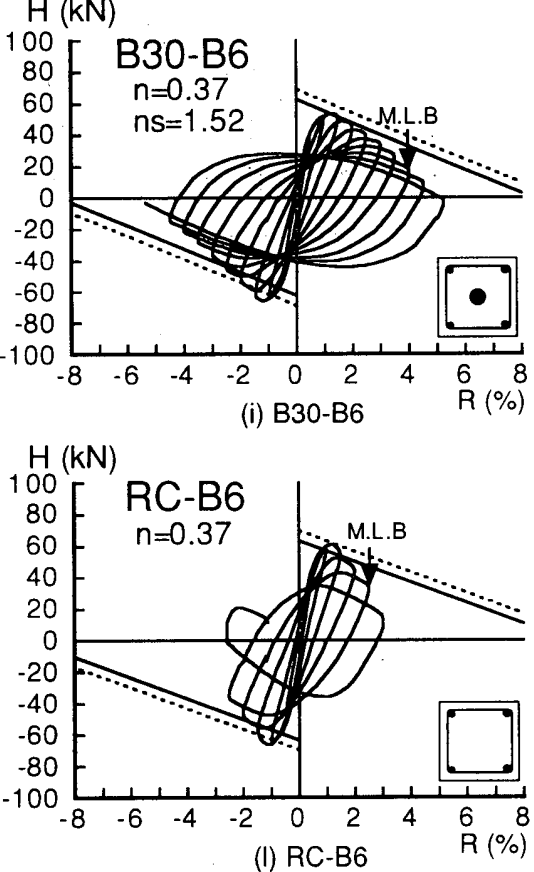

剥落がおこった， $\mathrm{RC}$ 柱は 2 体とも主筋の座屈発生後, 軸力を保持で きず崩壊したＳ１5-B6 を除く芯鉄骨合成柱および通常 SRC柱はコ ンクリートの圧壊および主筋の座屈が起こったが, 実験終了まで軸 力を保持でき，急激な耐力低下を伴う崩壊現象は見られなかった。 S15-B6 は内藏鉄骨の圧縮耐力に対する作用軸力の比ns が2.4であ り, 内蔵鉄骨の軸力に対する支持能力が少ないために, 最終段階で 軸力を保持できなかった。

\section{4 .2 水平力 - 部材角関係}

図3中, 実線は柱脚フェイス位置に塑性ヒンジが生じ塑性崩壊機 構を形成すると仮定したときの水平耐力であり,転倒モーメントの
影響を考慮して，次式で算定した。

$H=M p c / L-N \delta / L$

ここで, Mpcは鋼材の実降伏応力度とコンクリートのシリンダー 強度を0.85倍して計算した一般化累加強度である(表4中の Mpc1). $\mathrm{L}$ は材長 $(80 \mathrm{~cm}), \mathrm{N}$ は柱軸力, $\delta$ は水平力加力点の水平変位である.

同図中, 点線は(1)式の Mpcに鋼材の実降伏応力度とシリンダー強 度で計算した一般化累加強度を用いたものである(表4中の Mpc2). S15-B6を除く芯鉄骨合成柱㧍よびSRC柱は最大耐力発揮以後, か 


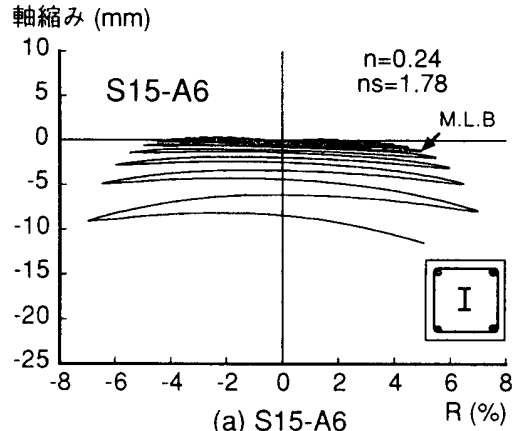

(a) S15-A6

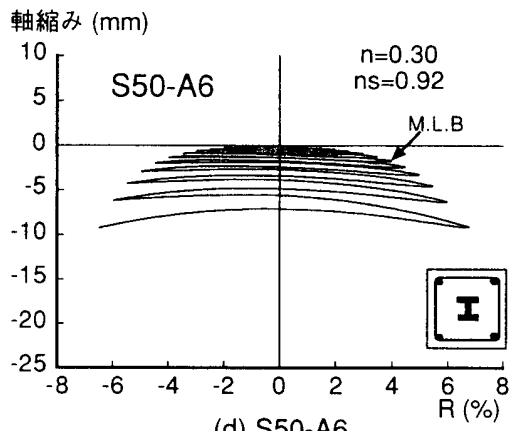

(d) $\mathrm{S} 50-\mathrm{A6}$

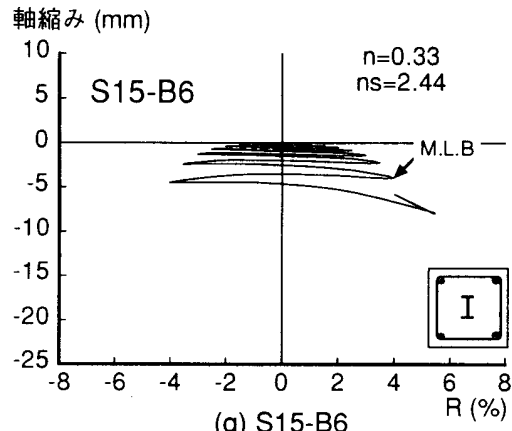

(g) S15-B6

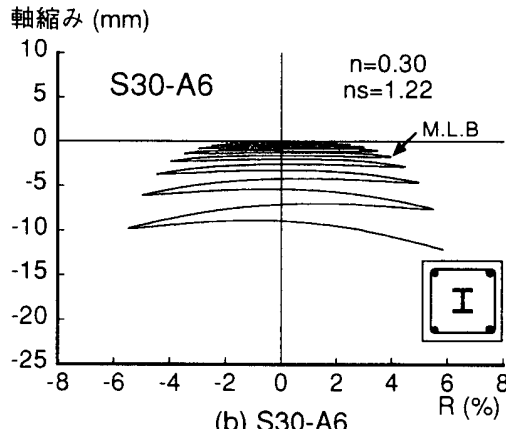

(b) S30-A6

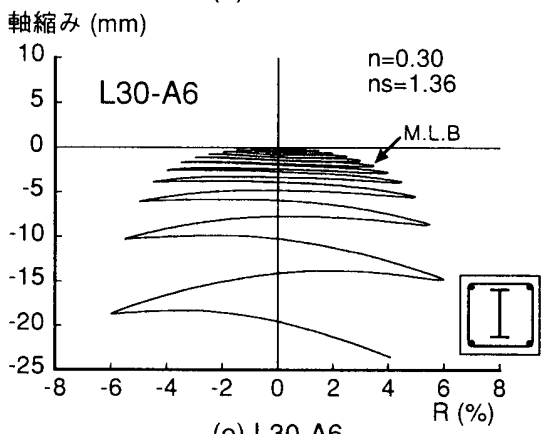

(e) L $30-A 6$

（l) 軸力比 $n=0.3$ の軸力載荷時

軸縮み $(\mathrm{mm})$

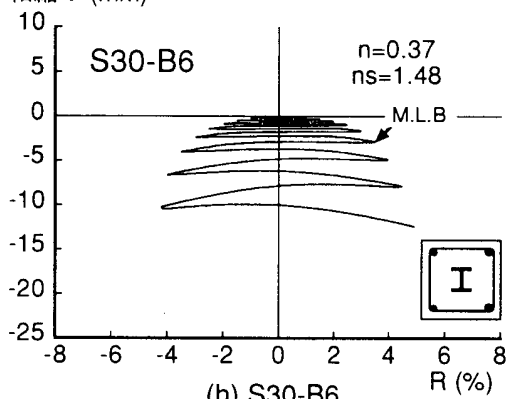

(h) $\mathrm{S} 30-\mathrm{B} 6$

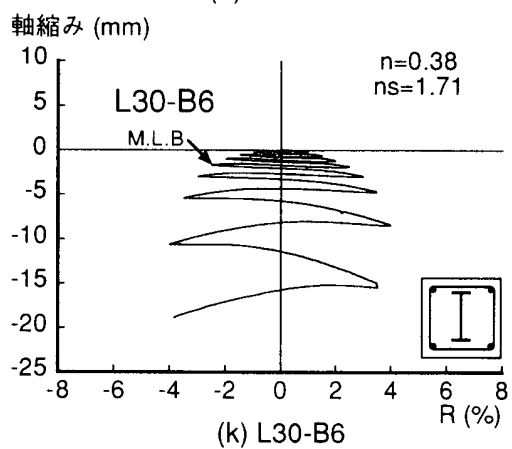

(II) SRC 規準制限軸力載荷時

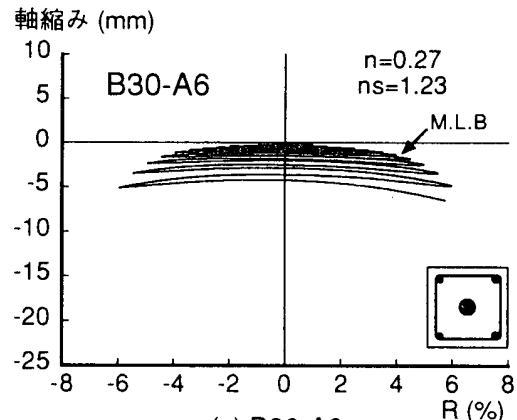

(c) B30-A6

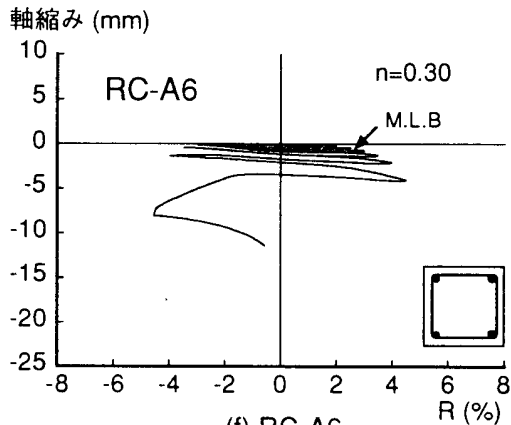

(f) RC-A6

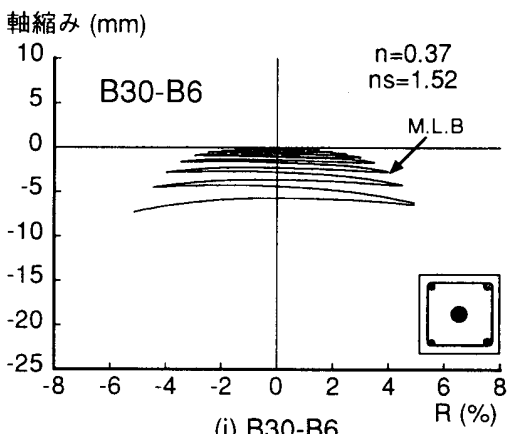

(i) $\mathrm{B} 30-\mathrm{B} 6$

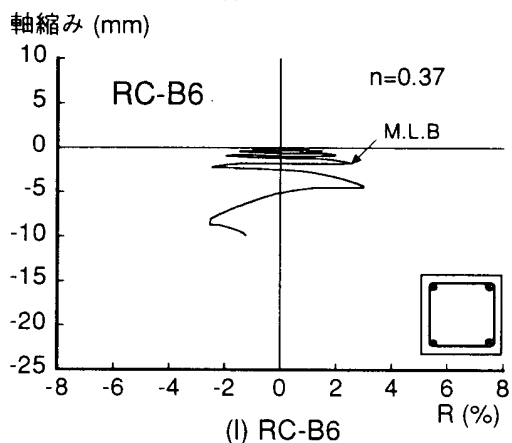

図 4 柱の材軸方向縮みと柱部材角関係

ぶりコンクリートの圧壊拉よび主筋の座屈により耐力が徐々に低下 しているが大変形域まで軸力を保持できており, 水平力が無くなる まで紡錘形の履歴挙動を示している．S15-B6は部材角Rが4.5/100 rad. 時に軸力を保持できず崩壊した。

一方, $\mathrm{RC}$ 柱は最大耐力発揮以降, かぶりコンクリートの圧壊に より耐力が低下し, 主筋の座屈の発生とともに軸力を保持できず崩 壊し，急激に耐力が低下している。

\subsection{3 軸方向変形性状}

図4に材軸方向の縮みと柱部材角の関係を示す (S50-B6 試験体の 実験デー夕はとれなかった， $\mathrm{RC}$ 柱は軸縮みが $5 \mathrm{~mm}$ 程度では軸力
を支えているが，それ以上の変形では，ひずみが急激に発散し，柱 材長の $1 / 100$ の $8 \mathrm{~mm}$ 縮んだ段階で軸力を保持できず崩壊している. 一方, 芯鉄骨合成柱㧍よびSRC柱は軸縮みが $10 \mathrm{~mm}$ 以上となっても， 内蔵鉄骨が作用軸力に対して, 3.1.2項で述べる適切な量が挿入され ていれば軸力を保持できている（同図(a),(b),(d),(e),(h),(k))。さら に，芯鉄骨としてコンパクトな断面である異形鉄筋を用いた B 30A6，B30-B6 は部材角が5/100 rad. 程度の大变形に至っても軸縮みの 発散は抑制されており，10mm まで縮んでいない(同図(c), (i))。軸 力に対して内蔵鉄骨が少ないS15-B6 試験体は部材角 R が5.5/100 $\mathrm{rad}$. で軸縮みが発散し, 軸力の保持が不能となっている(同図 $(\mathrm{g}))$. 


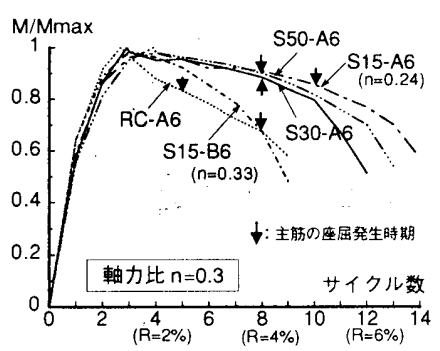

(a) 軸力比 0.3

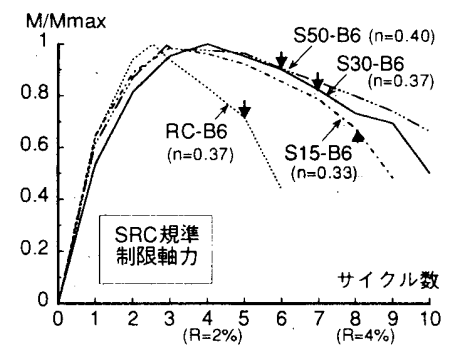

(b) SRC 規準制限軸力

(l) 芯鉄骨量の違いによる影響

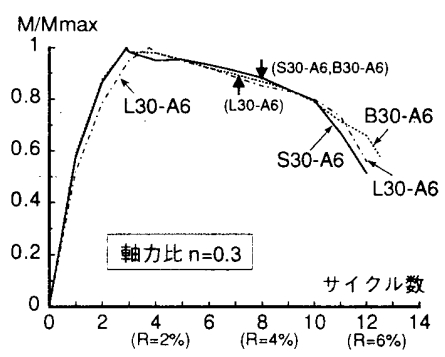

(c) 軸力比 0.3

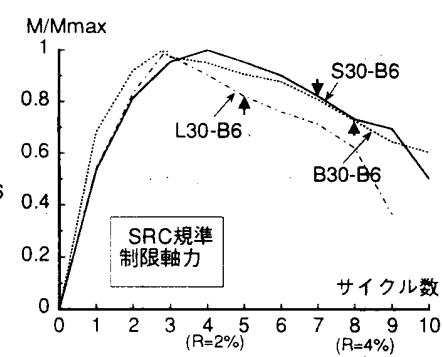

(d) SRC 規準制限軸力

図 5 除荷点における柱脚抵抗モーメントの挙動

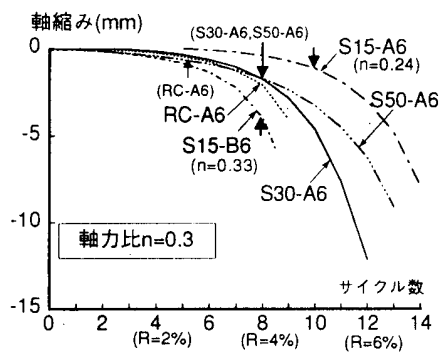

(a) 軸力比 0.3

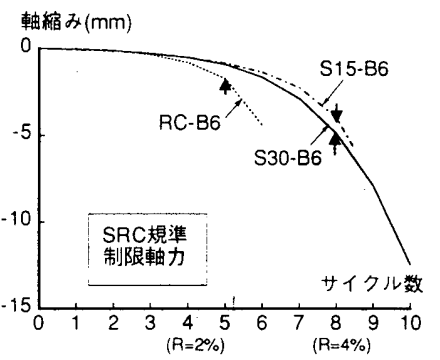

(b) SRC 規準制限軸力

(l) 芯鉄骨量の違いによる影響

図 6 除荷点における柱軸縮み

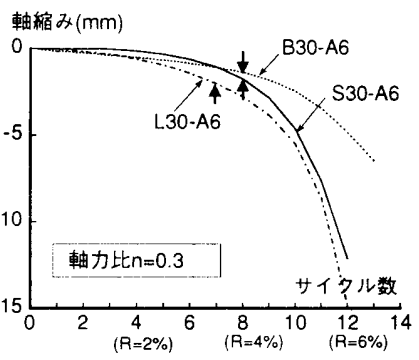

(c) 軸力比 0.3

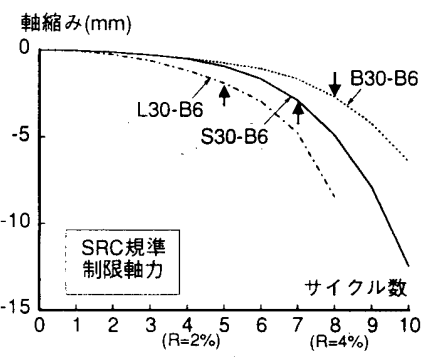

(d) SRC 規準制限軸力

(II) 芯鉄骨の断面形状の違いによる影響

\section{3. 考察}

\section{1 弾塑性挙動}

図5に各除荷点における柱脚フェイス位置での抵抗モーメントと サイクル数を示す.程軸は柱脚での抵抗モーメントを各試験体の最 大抵抗モーメントで除し無次元化している。横軸は載荷サイクルを 示しており，各変位振幅における除荷点に対応させたものである。 図6は軸縮みとサイクル数を示している.

\subsection{1 内蔵鉄骨の有無の影響}

図 5(a), (b)にRC 柱と芯鉄骨合成柱の曲げモーメントの挙動を示 す， RC 柱は，主筋が座屈することにより，軸力を保持できず不安 定となり，急激な抵抗力の低下が見られる。一方，S15-B6を除く芯 鉄骨合成柱および通常 SRC 柱は大変形域で主筋が座屈しても軸力 を保持できており，急激な抵抗モーメントの低下にはつながらな かった。これは、コンクリートの圧壊および主筋の座屈時の柱部材 角が RC柱に比べ大きな変形域で起こっていること,さらに図6(a), (b)に示すように芯鉄骨が軸方向力に効いているため, 軸維みに対寸 る剛性および変形能力が RC柱に比べ大きいことによる。芯鉄骨合 成柱は軸力に対し適切な量が挿入されてい机ば,軸方向力を最終段 階まで支持できたことより， $\mathrm{RC}$ 柱の軸力保持不能となる崩壊を防 ぐ補強法の一つとして有効であると考えられる。

\section{1 .2 内蔵鉄骨量の影響}

S15-B6 試験体は SRC 規準の制限軸力を受けているがその軸力が 断面圧縮耐力の 0.33 であるため, 軸力比 0.3 の他の試験体とも比較 できる。この試験体は鉄骨の压縮耐力に対する作用軸力の比 ns が 2.4 程度であり，最終段階で軸力を保持できず，軸力比 0.3 の RC 柱 と同様な挙動を示す結果となっている(図5(a))。さらに軸縮み性状 も RC-A6よりも剛性が小さいことおよび崩壊時の縮み量も RC柱に 対しあまり改善されていない（図6(a)）ことから，nsがこの程度で あると芯鉄骨の効果はあまりないものと考えられる。 $\mathrm{ns}$ が 1.5 程度であれば大変形域においても軸力保持不能となる崩 壊とはならない（図5(a)のS15-A6，S30-A6および図5(b)のS30-B6） ため,この程度の芯鉄骨量を挿入すれば効果があらわれるものと考 えられる。

芯鉄骨量を増やしnsの值を 1.5 以下となるようにしても，最大耐 力発揮以降の耐力の低下率及び部材角4/100rad.までの軸縮み量に関 してその効果はあまり上がらない（図 5(a)および図6(a) のS30-A6 と S50-A6 および図 5(b)のS30-B6 と S50-B6の比較).

以上のことから芯鉄骨として有効に働く適切な量が存在すると考 えられ，コンクリート強度，芯鉄骨の降伏応力度㧍よび芯鉄骨の圧 縮耐力に対する作用軸力が因子であると推測される.本実験の条件 下では，芯鉄骨の圧縮耐力に対寸る作用軸力の比 ns が 1.5 程度とな るように挿入すれば芯鉄骨は有効に㗢くものと考えられる。なお， この適切な量については柱の弾塑性解析を行った上で検討し, 続報 で報告する予定である。

\subsection{3 内蔵鉄骨の形状の影響}

H形鋼を捜入した場合とコンパクトな断面である異形鉄筋棒を用 いた場合で比較すると，曲げ性状は両者殆ど変わらないが（図 5(c) のS30-A6 と B30-A6 および同図(d)の S30-B6 とB30-B6の比較)，コ ンパクトな断面を用いた方が大変形域において軸縮み量が抑制され ている(図 6(c)のS30-A6 とB30-A6 および同図(d)の S30-B6 とB30$\mathrm{A} 6$ の比較). 芯鉄骨を挿入する意義を軸縮みを抑制させコンクリー トの応力およびひずみの発散を低減し, 軸力保持不能となる崩壊形 を防ぐことにあると考えると，曲げに殆ど寄与せず圧縮材として抵 抗できる、コンパクトな断面を用いた方が芯鉄骨の効果としては大 きいものと考えられる. 本実験のような小さなせいのH形鋼を挿入 しても，曲げに抵抗している（固定端からコンクリート断面せいの $1 / 4$ 上がったところで芯鉄骨フランジ表面に貼付した歪みゲージで 引張り側フランジの降伏を確認）ため, 異形鉄筋に比べ圧縮軸力の 
負担が少なくなることがその理由である。なお，H形鋼フランジに 挟まれたコンクリートはわずかな量であり，H形鋼を挿入した場合 と異形鉄筋を用いた場合で芯鉄骨近傍のコンクリートの拘束効果は 殆ど同程度であると考えられる。

$\mathrm{SRC}$ 柱と芯鉄骨合成柱を比較すると, 軸力比が 0.3 程度であれば, 両者の曲げ性状，軸縮み性状は殆ど変わらないが（図 5(c) および図 6(c)の S30-A6 と L30-A6の比較)，SRC 規準に定める制限軸力のも とでは芯鉄骨合成柱の方がSRC柱に比べ，曲げ抵抗力の低下率およ び軸縮み性状とも優れている（図5(d)および図6(d)のS30-B6 と L30B6の比較)．芯鉄骨合成柱が有利になる理由としては，せいの小さ な芯鉄骨よりも,引張り側フランジが断面中心より離れたSRC断面 の方が内蔵鉄骨の負担する引張り力が大きくなるため, コンクリー 卜に作用する圧縮力が大きくなることによるものと考えられる。

\section{2 曲げ耐力}

表4に実験による正側と負側の最大曲げ耐力を記している. 表中， 計算曲げ耐力は, 鋼材の実降伏応力度抢よびコンクリートのシリン ダー強度を 0.85 倍して計算した一般化累加強度（表 4 中 Mpc1）と 鋼材の実降伏応力度とシリンダー強度をそのまま用いて計算した一 般化累加強度（表 4中 Mpc2）を計算している．また，表中，実験值 と計算值の比較に用いた実験耐力は正負曲げ耐力の平均值を用いて いる，芯鉄骨合成柱は Mpc1で，RCおよびSRC柱についてはMpc2 で安全側に精度よく評価されていると考えられる。

芯鉄骨合成柱の耐力を累加強度で算定することおよびコンクリ一 卜強度を 0.85 倍した理由は以下のことによる。

図 7 に断面の軸力 - 曲げモーメント相関曲線を示す．図中○は実 験の正負曲げ耐力をプロットしたもので, ははそれらを平均したも のである. 芯鉄骨の耐力を無視し RC 断面の耐力で合成断面の耐力
を評価すると、特に低軸力下では断面曲げ耐力は安全側すぎる評価 となり，芯鉄骨と RCの累加で評価すべきであると判断した．固定 端からコンクリート断面せいの $1 / 4$ 上がったところでの芯鉄骨に貼 付した歪みゲージの計測結果では, 最大酎力発揮時には全試験体と もフランジ，ウエブ共に降伏していることが確認できた。このこと より実験の最大酎力はコンクリートの圧壊および内蔵鉄骨の降伏で 決まっていることがわかる.累加強度を求める上で断面におけるコ ンクリート応力を矩形分布としていることから，実験柎力を評価す るにはコンクリート強度を低減する必要があることによる。本実験 の範囲内では, 鉄骨比が少ない程, 低減係数の值を大きくとれるも のの，鉄骨比が大きくなると小さくすべきことから，実験曲げ耐力 の下限值を与える低隇倸数 0.85 で評価すべきものと判断した.

\section{3 変形能力}

柱部材がある限界状態までに吸収した累積エネルギーを図8(a)に 示すような理想弾塑性型のエネルギーと等価になるようにしたとき の塑性変形倍率 $\mu$ を算定した。ただし，Mpcは3.2 項で算定した累 加強度とし，芯鉄骨合成柱部材については Mpc1で, SRC およびRC 部材については Mpc2 で計算している．弾性限部材角 Rpcは，片持 ち柱の断面の弾性曲げ剛性を計算し，部材端がMpcに達したときの 部材角である.断面の弾性曲げ剛性はコンクリートの剛性と鋼材の 剛性の和として求めた。

\subsection{1 曲げ抵抗力の限界状態に対する変形能力 Rm90}

曲げ抵抗力の限界状態として実験最大曲げ耐力Mmaxの $90 \%$ まで 曲げ耐力 M が低下した段階（(2) 式）とした。

$$
M / M_{\max } \geq 0.9
$$

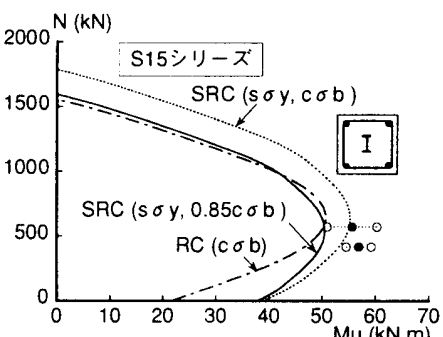

(a) $\mathrm{S} 15$ シリーズ

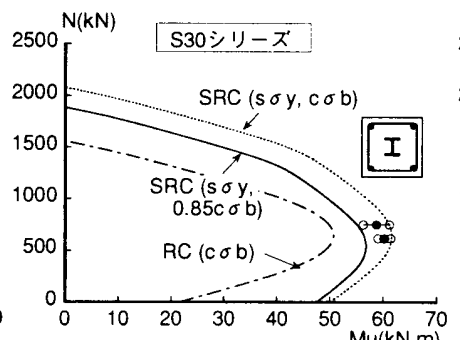

(b) S30 シリーズ

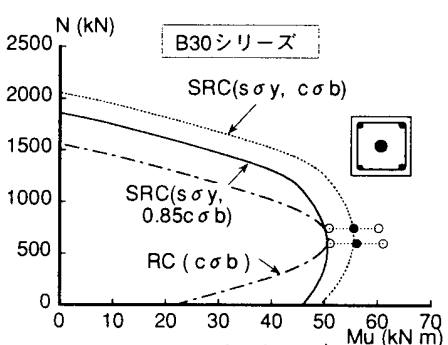

(c) $\mathrm{B} 30$ シリーズ

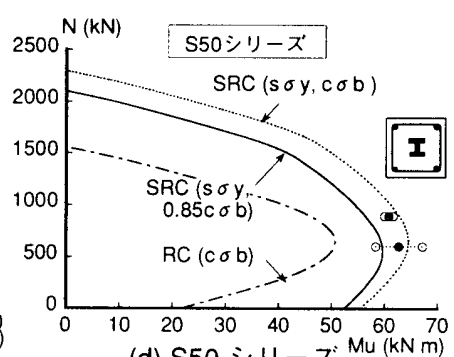

(d) $\mathrm{S} 50$ シリーズ $\mathrm{Mu}(\mathrm{kN} \mathrm{m})$

図 7 芯鉄骨合成柱の実験耐力と一般化累加強度

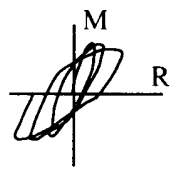

E:限界状態までに吸収した累積エネ ルギーの半分 (一方向载荷に対応 するように

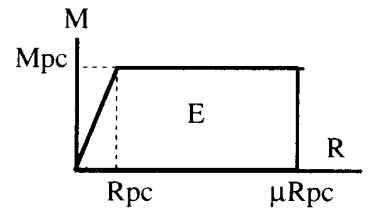

(a) 塑性変形倍率

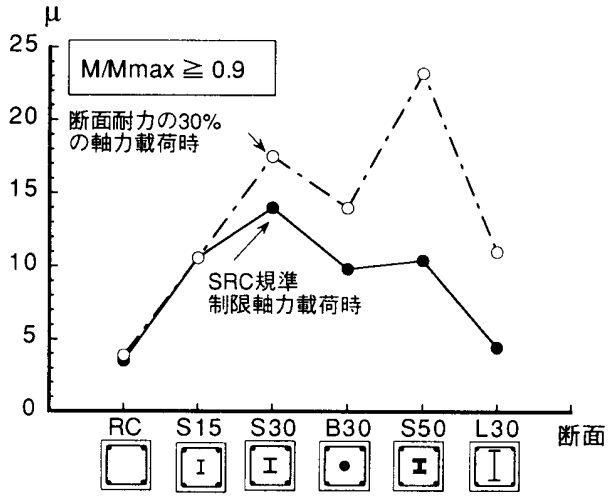

(b) 最大耐力の $90 \%$ まで低下した段 階での塑性変形倍率

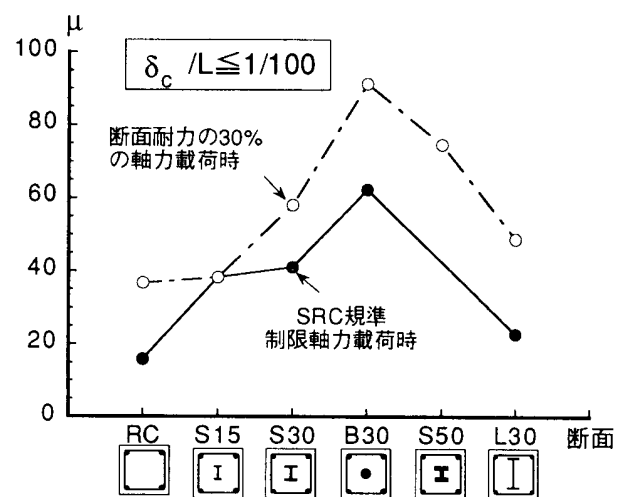

(c) 軸縮みが材長の $1 / 100$ まで縮んだ段 階での塑性変形倍率

図 8 変形能力 
この条件を満たす芯鉄骨合成柱の最大部材角は, 軸力比 0.3 程度 の軸力を受ける試験体では 3/100〜 4/100 rad， SRC 規準に定める制 限軸力を受ける試験体では 2/100〜3/100rad.であった。

本限界状態に対する変形能力を図8(b)に示す.但し,S15-B6をS15 シリーズのSRC制限軸力下抢よび軸力比 0.3 実験值として考察す る.軸力比が 0.3 の場合には芯鉄骨合成柱部材は RC柱の変形能力の 3 倍から 4 倍, SRC 規準に定める制限軸力のもとでは 2 倍から 3 倍 あることがわかる．SRC 規準に定める制限軸力のもとではSRCと $\mathrm{RC}$ の変形能力は殆ど同じであることから，このような高軸力のも とでの芯鉄骨の効果は大きいものと捉えることができる。さらに， このような高軸力のもとではS30-A6がS50-B6よりも変形能力に優 れていることから，芯鉄骨の最適な量の存在があることがわかる. 3.3.2 軸縮み量の限界状態に対する変形能力 Rd1

RC 柱が崩壊するまでに吸収したエネルギーに対して芯鉄骨合成 柱部材が吸収したエネルギーがどの程度あるのかを評価するため, $\mathrm{RC}$ 柱試験体が軸力を保持できなくなる, 軸縮み $\delta \mathrm{c}$ が材長 $\mathrm{L}$ の $1 / 100$ まで維んだ段階を限界状態（(3) 式）として変形能力を検討した。

$$
\delta_{c} / L \leq 0.01
$$

芯鉄骨合成柱およびSRC柱がこの限界状態に達した段階では, 柱 脚での抵抗モーメントは最大抵抗モーメントの6割から7割程度ま で低下している段階である。しかしながらこのような段階でも。芯 鉄骨合成柱およびSRC柱は軸力を保持できることから落階に至らし める崩壊現象は免れるものと考えられる。この限界状態は，階高 $4 \mathrm{~m}$, スパン $8 \mathrm{~m}$ 程度の骨組で, 中柱が殆ど縮まないものと考えると, 変動軸力を受ける側柱が材長の $1 / 100$ 縮んだ段階では，梁および床 スラブは部材角で $1 / 200$ 程度変形することに対応している。

本限界状態に対する変形能力を図 8 ( c c ) に示す. 軸力比が 0.3 程 度では芯鉄骨合成柱の変形能力は $\mathrm{RC}$ 柱の 1.5 倍から2 倍程度あるこ と, SRC 規準の制限軸力下では 2 倍から 3 倍程度であることがわか る。軸力比が約 0.3の S15-B6 は殆ど RC 柱（RC-A6）と同様な変形 能力に留まっていることから，芯鉄骨の圧縮酎力に対する作用軸力 の比nsが 2.5 程度となる芯鉄骨を挿入しても殆ど効果は期待できな w.

このような限界状態に対する変形能力で評価すると, 同じ鉄骨量 を挿入していても，内蔵鉄骨として，曲げに殆ど効かず，軸力のみ に抵抗できるコンパクトな断面である異形鉄筋龬棒を挿入する方が $\mathrm{H}$ 形鋼を挿入するより変形能力の点で優れている.

\section{4. 結論}

一定圧縮軸力と繰返し水平力を受ける芯鉄骨合成柱の載荷実験を 行った結果，以下のことが明らかとなった。

1）芯鉄骨を RC 柱に挿入することにより，高軸力下での RC 柱の変 形能力を大きく改善できる。
2）内蔵鉄骨の圧縮耐力に対する柱の作用軸力の割合が芯鉄骨合成 柱の挙動に及はす影響は大きく、この值が 1.5 程度であ机ば安定 した性状を示し, 大変形域において RC柱に見られるような軸力 保持不能となる崩壊現象は見られない。

3) 芯鉄骨合成柱の曲げ耐力は, コンクリート強度としてシリンダー 強度を 0.85 倍したものと鋼材の降伏応力度を用いて計算した一 般化累加強度で，ほほ評価できる。

4）芯鉄骨を有効に効かせる鉄骨量が存在し，それ以上鉄骨量を増 やしても鉄骨量の増加分に対する効果は少ない. 本実験の条件下 では, 内蔵鉄骨の圧縮耐力に対する柱の作用軸力の割合nsを 1.5 となるように芯鉄骨を挿入することが最も効率的であると云え る。

5）芯鉄骨の断面形状は， $\mathrm{H}$ 形鋼よりも，曲げに殆ど抵抗できず軸力 に抵抗できる、コンパクトな断面である異形鉄筋鋼棒を用いた方 が，軸縮みの進行が抑制できる。

\section{謝辞}

本研究は平成 9 年度文部省科学研究費 (奖励研究 $(A)$ )課題番号 （09750664）研究代表者：堺 純一）およびS.P.RC柱研究会（委員 長: 福山大学 南 宏一教授) の助成を受けて行った. 実験および 討議に際し, 巟玉憲助氏 (九州大学大学院), 中村信彦氏 (九州大学 卒業，現住友金属）の協力を得ました。さらに実験に際し，九州大 学技官, 有働文久氏, 川口 晃氏, 久島昭久氏, 津賀山健次氏のご 協力を受けました。ここに記して感謝いたします。

\section{参考文献}

1）日本建築学会・鉄筋コンクリート構造運営委員会・勒性設計小 委員会, 勒性設計小委員会報告書（終局強度型耐震設計法に関 連する最新の研究成果), 線材 WG 報告書, pp.12-46, 1992 年 8 月。

2）滝口克己, 長嶋俊雄: 高強度材料を用いた小鉄骨 SRC 柱の耐力 と変形性能の評価, 日本建築学会構造系論文集, 第 490 号, pp.229-235，1996 年 12 月.

3）滝口克己, 長嶋俊雄, 伊礼朋次: 高強度材料を用いた小鉄骨 SRC 柱の繰り返し荷重下における耐力, 日本建築学会構造系論文集, 第 466 号, pp.155-163，1994 年 12 月.

4) 日本建築学会：鉄骨鉄筋コンクリート構造計算規準 ·同解説, 1987 年, 6 月.

5）村田耕司, 東端泰夫, 長嶋俊雄：鉄骨鉄筋コンクリート柱の曲げ 性状に関する研究, 第 13 回コンクリート工学年次論文報告集, pp.351-356, 1991 年.

6）児玉憲助, 松井千秋, 堺 純一, 平川葉子, 中村信彦：芯鉄骨合 成柱の耐霞性能に関する実験的研究, 日本建築学会九州支部研 究報告，第 37 号，pp. 509-512，1998 年 3 月

（1999年 2 月10日原稿受理，1999年 7 月13日採用決定） 